\title{
Plant Available Moisture in Stone-soil Media for Use Under Pavement While Allowing Urban Tree Root Growth
}

\author{
Jason Grabosky, Edward Haffner, and Nina Bassuk
}

\begin{abstract}
Three avenues of experimental observation detail aspects of plant available water holding capacity in compacted stone-soil media designed for urban tree establishment in paved situations. The various compacted media provided an estimated plant available moisture content of $7 \%-11 \%$ by volume, comparable to a loamy sand. Changes in aggregate and of soil influenced initial field capacity moisture content, but high matric potential moisture content was consistent, presumably as a reflection of the aggregate content of the designed system. A large portion of plant available moisture was weakly held in large voids, consistent with related infiltration and permeability data, and could be an influence in water storage and irrigation planning to use layers of designed soils in a layered pavement section for urban vegetation.

Key Words. Stalite; Structural Soil; Plant Available Moisture.
\end{abstract}

Urban tree establishment, particularly when a tree is planted close to pavement, can become problematic for the tree and/or the pavement. High levels of soil and base course compaction to support pavement typically impedes or excludes root growth, limiting access to the water and mineral resources they contain. Several designed soil systems have been advanced to integrate pavement section design and tree root growth in spaces where trees are close to pavement with limited soil resources (Costello and Jones 2003). Gap-graded, large aggregate-soil systems-at times referred to as structural, skeletal or bimodal soils-rely on an aggregate matrix to meet pavement design needs by having aggregates form a load-bearing matrix, or skeleton, while suspending soil as a rooting medium within the interconnected voids within the aggregate matrix. While there are no published studies explicitly testing plant available moisture properties of these designed soils, there are several assumptions and opinions which vary widely regarding plant available moisture holding capacity and irrigation management. There is also a need to quantify water storage and drainage behavior such as system porosity, infiltration capacity and hydraulic conductivity prior to developing soil volumes designed to integrate storm water management and urban canopy development into a paved site.

The following three studies were conducted to define compacted porosity, infiltration, and plant available moisture in varied CU Structural Soil ${ }^{\mathrm{TM}}$ mixtures, with the third study also using Carolina Stalite Structural Soils ${ }^{\mathrm{TM}}$ (henceforth termed CU and CS, respectively). Stalite is a heat-expanded slate which has been reasonably assumed to provide a greater plant available moisture content over a traditional aggregate given its rough surface and porous nature. The testing of different soil and aggregate components in the following studies reflect the time and location differences in the testing effort, but also reflect the component variability which might be encountered by regional availability of soils and aggregates.
Developing empirical data for cultural management of plant materials growing in compacted systems can assist in assigning root zone soil volumes of the stone-soil mixtures with regard to irrigation scheduling and stormwater management consideration.

\section{MATERIALS AND METHODS}

\section{Initial Studies 1996-1997}

Three tests were conducted from a CU mix design, representative of a compacted field installation. The tests were designed to assess consistency in sample preparation and porosity for laboratory testing, define plant available moisture in compacted samples using a standard desorption plate method (Topp et al. 1993), and define hydraulic conductivity (see Table 1 , for protocol testing methods used). These tests were in prepared compacted samples. In the first test, six samples were tested to check for system and sample consistency. In the second test, three samples were used in plate desorption testing, but repeated plate failures on other replicates limited data collection. A final two-point sample test for constant head hydraulic conductivity in compaction permeameters was used to describe the behavior in compacted samples.

A CU was developed from a gravimetric ratio of $83 \%$ blocky crushed limestone NYSDOT \#2 [2.5-1.25 cm (1-0.5 in) range in size] aggregate (NYSDOT 702-02, 1990), 17\% shredded clay loam and an agricultural hydrogel $(0.025 \%)$ used as a system stabilizer during mixing and placement (Gelscape hydrogel, Amereq, New City, NY). For consistency of data between horticulture and engineering protocol and to minimize potential sidewall effects in sample behavior given the size of the aggregate, the samples were prepared and compacted into $15.24 \mathrm{~cm}$ (6 in) i.d. California Bearing Ratio testing molds of $2317 \mathrm{~cm}^{3}$ $\left(141.4 \mathrm{in}^{3}\right)$ with a standard effort of $592.7 \mathrm{~kJ} \mathrm{~m}^{-3}(12,375 \mathrm{ft} \mathrm{lbf}$ $\mathrm{ft}^{-3}$ ) (protocol references Table 1, data Table 2). Six samples were 
Table 1. Listing of testing protocol and system dimensions used from standardized methods.

\begin{tabular}{|c|c|c|}
\hline $\begin{array}{l}\text { AASHTO } \\
\text { designation } \\
\text { (pages) }\end{array}$ & $\begin{array}{l}\text { ASTM Test } \\
\text { method } \\
\text { designation } \\
\text { (pages) }\end{array}$ & Protocol title \\
\hline M 43 & D448 & $\begin{array}{l}\text { Standard classification for sizes of } \\
\text { aggregate for road and bridge } \\
\text { construction }\end{array}$ \\
\hline $\begin{array}{l}\text { Т } 85-91 \\
(85-88)\end{array}$ & $\begin{array}{l}\text { C-127-88 } \\
(64-68)\end{array}$ & $\begin{array}{l}\text { Test method for specific gravity } \\
\text { and absorption of coarse aggregate }\end{array}$ \\
\hline $\begin{array}{l}\text { Т 99-94 } \\
(123-128)\end{array}$ & $\begin{array}{l}\text { D698-91 } \\
(77-84)\end{array}$ & $\begin{array}{l}\text { Test method for laboratory } \\
\text { compaction characteristics of soil } \\
\text { using standard effort } 12,400 \mathrm{ft}-\mathrm{lb} / \\
\mathrm{ft}^{3}\left(600 \mathrm{kN} * \mathrm{~m} / \mathrm{m}^{3}\right)\end{array}$ \\
\hline $\begin{array}{l}\text { Т 100-93 } \\
(129-132)\end{array}$ & $\begin{array}{l}\text { D-854-92 } \\
(88-91)\end{array}$ & $\begin{array}{l}\text { Test method for specific gravity of } \\
\text { soils }\end{array}$ \\
\hline $\begin{array}{l}\text { Т 191-93 } \\
(367-369)\end{array}$ & $\begin{array}{l}\text { D1556-90 } \\
(120-125)\end{array}$ & $\begin{array}{l}\text { Test method of density and unit } \\
\text { weight of soil in place by the } \\
\text { balloon sand cone method }\end{array}$ \\
\hline $\begin{array}{l}\text { T } 193-93 \\
(373-378)\end{array}$ & $\begin{array}{l}\text { D1883-94 } \\
(159-165)\end{array}$ & $\begin{array}{l}\text { Test method for CBR (California } \\
\text { Bearing Ratio) of laboratory } \\
\text { compacted soils }\end{array}$ \\
\hline $\begin{array}{l}\text { T } 215-70 \\
(434)\end{array}$ & $\begin{array}{l}\text { D2434-68-94 } \\
(202-206)\end{array}$ & $\begin{array}{l}\text { Test method for permeability of } \\
\text { granular soils (constant head) }\end{array}$ \\
\hline
\end{tabular}

saturated by slow immersion over 5 days. While submerged, the sample was moved to a plastic bottom cover seal and sample mass determined immediately after removal from the water bath. Samples were then allowed to drain for 3 hours [sample depth $12.7 \mathrm{~cm} \mathrm{(5} \mathrm{in)]} \mathrm{and} \mathrm{re-weighed} \mathrm{to} \mathrm{estimate} \mathrm{macropores} \mathrm{from} \mathrm{free}$ drainage. Porosity was calculated as a function of total sample dry density using a system bulk specific gravity of 2.688, which was developed from tested soil and aggregate components (Grabosky 1996) for the study with the assumption of one unit volume in the mass to volume conversion. An appendix describes weight/ volume conversions with phase diagrams (Grabosky 1999).

Three samples were prepared and saturated over seven days on ceramic $100 \mathrm{kPa}$ (1 bar) desorption plates with sil- ica flour contact medium (SoilTest) in deep soil pressurization cells. Attempts to develop data at higher pressure failed due to repeated fracture of ceramic plates under the large sample mass. Two stone-soil samples were prepared and compacted into molds and tested for constant head hydraulic conductivity (Table 1) with SoilTest K 612-A compaction permeameters (ELE International LLC/Soiltest Loveland, CO).

\section{Planted Study, Florida 2002}

In this study, two soils were tested as components in a common stone matrix to observe influence on plant available moisture. The test developed an estimate of plant available moisture in a compacted CU system using evapotranspiration to de-water the mix samples. Traditional soil-moisture characteristic curves were infeasible due to sample size and plate breakage observed in the earlier studies. Direct measurement of matric potential by insertion of tensiometers was impractical due to the dimensions of the stone and container as well as difficulty in achieving toolmedia contact without skewing the data with a column of contact medium such as sand. Predawn water potential was used as an estimator for bulk matric tension under the assumptions that the plant water status comes to near equilibrium with the container media at night and that the medium moisture over the volume of the container is uniform to a point where sampling errors are greater than system moisture gradients in an established containerized root system. The water potential data was linked to volumetric moisture content, developed from gravimetric measures (using phase diagrams), to plot moisture desorption curves (Williams and Araujo 2002). A oneway ANOVA was used to compare soil treatment test system definition parameters in Minitab v14 (State College, PA) after testing for equal variance.

Forty-eight rooted cuttings of $\times$ Cupressocyparis leylandii (A.B. Jacks. \& Dallim.) were established in plastic nursery containers $[15.3 \mathrm{~cm}(6 \mathrm{in})$ top diameter, $28.6 \mathrm{~cm}$ (11.3 in) container depth] from November 2001-May 2002. Two compacted $80 \%$ stone, $20 \%$ soil, and $0.025 \%$ hydrogel blends were tested (see Table 3 for media volumes). The aggregate for both mixes

Table 2. System descriptions for initial bench scale testing of stone-soil material desorption 1996-1997. Density determined from whole sample mass. Porosity determined by phase diagram (1-(mass of solids/specific gravity)) for $1 \mathrm{~m}^{3}$ of material. Volumetric moisture percentage $(\theta)$ at varied matric tensions measured as moist weight prior drying. Hydraulic Conductivity measured with compaction permeameter.

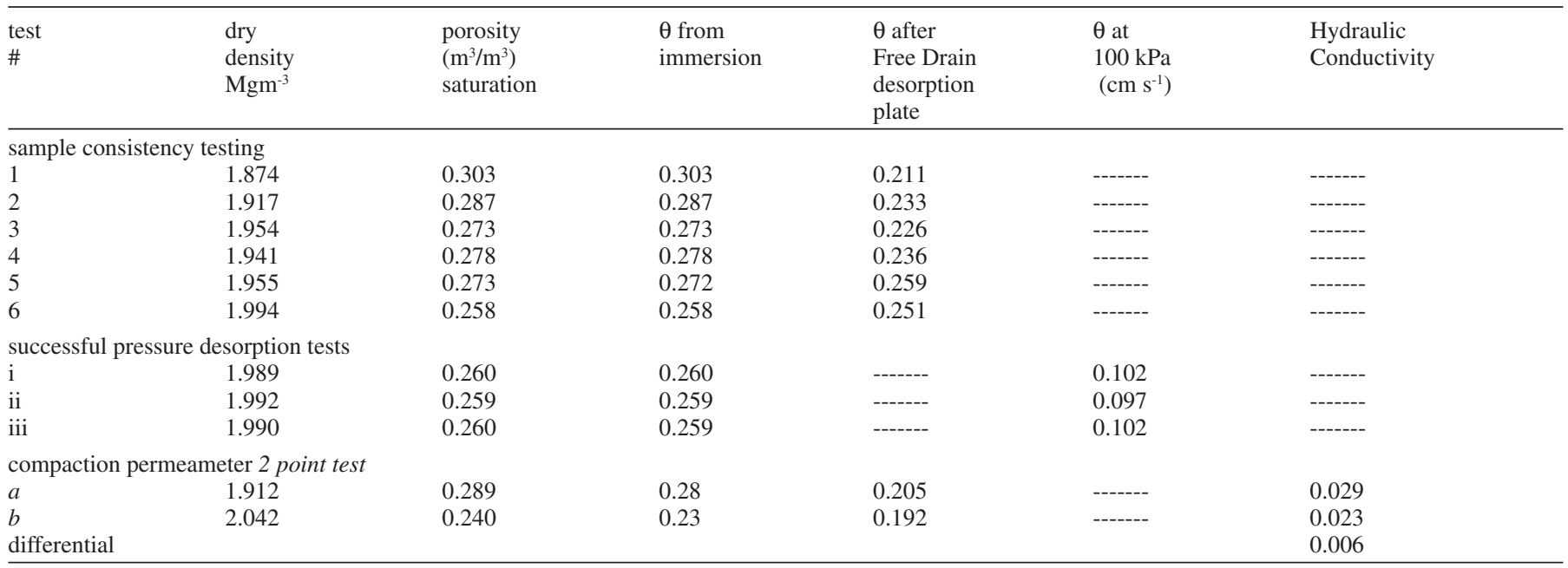


was a crushed limestone fitting ASTM D448 aggregate size \#4 [3.8-1.9 $\mathrm{cm}(1.5-0.75 \mathrm{in})$ range in size]. The soil component was a treatment variable within the stone matrix. The interstitial soil component compared sandy loam (68\% sand, $13 \%$ silt, $19 \%$ clay) to loamy sand ( $80 \%$ sand, $8 \%$ silt, $12 \%$ clay) with 24 treatment replicates in the test system. Materials were compacted with a vibratory plate tamper with a $2.5 \mathrm{~cm}(1$ in) diameter wooden dowel placeholder for later insertion of the test plants without compromising the compaction effort (Grabosky et al. 1996). While containers maintained a near-constant volume during compaction, they consistently split under higher compaction efforts to develop higher density levels. Final density at stable container volume, verified by container diameter after compaction, is listed in Table 3. Plants were arranged in a randomized complete block in November 2001, and grown as a nursery block in Gainesville, FL, U.S. with daily manual irrigation.

On May 28, 2002, the plant block was moved to a rain exclusion shelter to impose a dry-down sequence and watered to container runoff at $5 \mathrm{pm}$. Four of the plants in the loamy sand treatment were too small to provide repeated sampling tissue for the duration of the study, and three others had died in the nursery block, which means 7 of 24 replicates in the loamy sand treatment were lost from the study design, leaving 17 replicates in the loamy-sand treatment group. Gravitational drainage was measured by initial mass measurement at the predawn water potential measurement of the first day, since transpiration impact over a standard twenty-four hour span was not separated from gravitational water loss. The result was an initial test drainage time of 10.5 hours. Plants were measured daily from May 29 through June 13, 2002, for pre-dawn water potential in the field with a Scholander-Hammel pressure bomb (Scholander et al. 1964) on 3.8-6.4 cm (1.5-2.5 in) apical shoot sections, after measuring container mass for bulk gravimetric moisture loss. Plant sample fresh weight was measured to account for tissue losses in repeated predawn moisture sampling in the pressure bomb tests. Plant systems were separated from the media prior to drying and weighed to remove and account for plant fresh weight and tissue sample collection from soil moisture calculations. Total plant mass $[40.5 \pm 3.4 \mathrm{~g}(0.09 \mathrm{lb})]$ was assumed to stay constant compared to the total system mass $[22.3 \pm 0.2 \mathrm{~kg}(49.2 \mathrm{lbs})$ oven dry soil mass] over the 15-day testing period and balance sensitivity. Since plants were only a method of sampling, initial standardization and growth tracking data were not collected. Gravimetric data was converted to volumetric data using a bulk media specific gravity (from existing information of the local component materials) of 2.65 and converted by standard phase diagram methods after tabulating daily system mass measurements against the oven dry total sample to track moisture loss.

Pre-dawn plant water potential (as an estimate of matric potential) and volumetric moisture percentage scatter plots were developed to define plant available moisture estimates in the compacted stone-soil matrices. The plots were used to compare the impact of the differing soil source materials within the same aggregate skeletal lattice. Predawn water potential data was transformed into a negative exponential function (natural $\log$ ) and treatments were fit to a simple linear regression model comparing transformed water potential to system volumetric moisture content. Slope coefficients were compared in two-tailed $\mathrm{z}$ tests of the coefficient standard error to test the null hypothesis that there were no differences in the moisture release relationship beyond endpoint definitions (systems de-watered in same manner). Moisture content after free drainage was used as an estimator of initial field capacity, since no water was draining during the initial weighing sequence. Determination of an arbitrary permanent wilting point was not possible from linear regression models due to limited replicate observations at $1500 \mathrm{kPa}$ (15 bar). An endpoint was assigned at $1200 \mathrm{kPa}$ (12 bar) to use all system replicates available within the range of observation from the regression analysis to accommodate variation within treatment replicate behavior. In those limited cases where $1500 \mathrm{kPa}$ data was available, the difference in volumetric moisture percentage between $1500 \mathrm{kPa}$ and $1200 \mathrm{kPa}$ was less than $0.2 \%$, and in all cases the differences between 1200 $\mathrm{kPa}$ and the last previous observation [(ranging from 800-1100 $\mathrm{kPa}(8-11$ bar), data not shown)] was less than $0.4 \%$, greater than between replicate variation. Generalized treatment moisture content was derived from predicted values using the negative log transformed regression models. Given the slope of the moisture release relationship, the range of data from the plotted individual replicate release curves at low moisture (not reported) and typical moisture release characteristic curves the conservative estimator to suggest an endpoint for plant available moisture, derived from the mean observed free drainage minus the back-transformed $1200 \mathrm{kPa}$ moisture content from the regression equation.

Table 3. Treatment description for stone-soil systems in 2001 planted dry down study in Florida. Differences tested in ANOVA at $\alpha=0.05$ listed as significant if $P<0.001$.

\begin{tabular}{llll}
\hline $\begin{array}{l}\text { ASTM \#4 Limestone }(80 \%) \\
\text { Soil type (20\%) }\end{array}$ & $\begin{array}{l}\text { Loamy } \\
\text { sand }\end{array}$ & $\begin{array}{l}\text { Sandy } \\
\text { loam }\end{array}$ & Difference \\
\hline Replicate count in analysis & 17 & 24 & \\
Compacted density $\left(\mathrm{Mg} \mathrm{m}^{-3}\right)$ & $1.75 \pm 0.015$ & $1.66 \pm 0.014$ & y \\
Replicate soil volume $\left(\mathrm{m}^{3}\right)$ & $0.0134 \pm 0.0002$ & $0.0132 \pm 0.0002$ & $\mathrm{n}$ \\
Calculated porosity $\left(\mathrm{m}^{3} / \mathrm{m}^{3}\right)$ & 0.340 & 0.374 & \\
Free drain moisture $\left(\mathrm{m}^{3} / \mathrm{m}^{3}\right)^{*}$ & $0.137 \pm 0.003$ & $0.163 \pm 0.003$ & y \\
Dry end point moisture** & $0.059 \pm 0.003$ & $0.050 \pm 0.002$ & \\
$\left(\mathrm{~m}^{3} / \mathrm{m}^{3} @ 1200 \mathrm{kPa}\right.$ matric tension $)$ & & $11.3 \%$ & \\
Plant Available Moisture Estimation & $7.8 \%$ & &
\end{tabular}

* Moisture content and Standard Error of mean derived from initial data measures after 10.5 hours free drainage

**Moisture content and Standard Error of model fit values derived from predicted values $(\alpha=0.05)$ in simple linear regression (Minitab 14) using negative natural log transformed matric tension and volumetric moisture data. ANOVA not used on fitted data. 


\section{CU and CS Structural Soil Tests 2006}

In the third set of tests, two aggregates were tested as components with a common soil component. A planted study similar to the Florida study was used to de-water the test system replicates using two aggregates, crushed limestone and Stalite. Stalite is a heat-expanded slate offering a porous aggregate, but definition of its impact in a stone-soil blend had not been defined with regard to plant available moisture or system behavior. The testing series was also used to compliment and verify the observations of the two previous studies with regard to bulk system compaction testing and porosity. Finally, infiltration capacity in a compacted field application test was conducted.

A CU was produced with gravimetric ratio of $80 \%$ crushed limestone NYSDOT \#2 size aggregate $2.5-1.25 \mathrm{~cm}$ (NYSDOT _703, 2006), $20 \%$ silty clay loam ( $15 \%$ sand, $56 \%$ silt, $29 \%$ clay), and $0.025 \%$ hydrogel binder; and compacted with a standard effort (Table 1). A CS was produced as a volumetric mixture of $80 \% 2 \mathrm{~cm}$ expanded slate ( $3 / 4$ inch Stalite $\mathrm{Gs}_{\text {apparent }}=1.44$ per company specification, Stalite, Salisbury, NC), $20 \%$ silty clay loam (15\% sand, $56 \%$ silt, $29 \%$ clay), and compacted with a standard effort (Table 1). Resulting densities are reported in Table 4. No hydrogel was used in the CS, per company system specification (Carolina Stalite Co, 2007). Compacted unit weights of aggregates and conversion to matrix porosity was used to verify physical similarity between blends. In this case, the Stalite was treated as a solid aggregate in phase diagrams to compare to the gravel using the apparent specific gravity supplied by manufacturer. Apparent specific gravity is defined as a "ratio of the weight of an aggregate in air to a unit volume of the impermeable portion of the aggregate at a stated temperature to the weight of an equal volume in a gas free distilled water at a stated temperature" (AASHTO T-85-91 section 3.1.2.1). Data reported on porosity in Table 4 does not reflect explicit measures of voids within the aggregate itself. The provided specific gravity did, however, provide for the roughness and surface pores as a consequence of the test method (Table 1). The silty clay loam used in the CS mixture differed from the company specified sandy clay loam soil in order to compare aggregate type in the study and hold soil type constant (Carolina Stalite 2007). Compacted and gravitational porosity were developed as in the 1996 study (Table 4).

Five samples of each material and five samples of the soil component alone were compacted into $15.2 \mathrm{~cm}$ by $14.8 \mathrm{~cm}$ i.d. ( 6 in by 5.8 in i.d.) molds to peak density from standard compaction moisture density curves (Table 1), saturated with water and allowed to drain for three hours to establish a direct comparison to the initial study. The treatments were then compared to observe the differences in rapid drainage potential.

Fifteen testing replicates of each stone-soil mixture were compacted into $14.8 \mathrm{~cm}$ i.d. (5.8 in i.d.) P.V.C. tubes of $30.5 \mathrm{~cm}(12$ in) depth $\left(0.262 \mathrm{~m}^{3}\right.$ or $\left.0.184 \mathrm{ft}^{3}\right)$ following earlier protocol for compaction (Grabosky et al. 1996) to the densities described above. Rooted cuttings of Populus deltoides (Bartr. ex Marsh.)

Table 4. Treatment descriptions for stone-soil systems in 2006 planted dry down and field-testing in Ithaca, NY, U.S. Density and free drainage moisture were tested in both compaction testing and the plant dry down study at the aggregate treatment level in oneway ANOVA at $\alpha=0.05$ and were significant $P<0.001$. Soil alone was not tested, but shown for illustration in compaction testing.

\begin{tabular}{|c|c|c|c|}
\hline \multicolumn{4}{|l|}{ Isolated component testing } \\
\hline Aggregate & Gravel & Stalite & \\
\hline Aggregate Gs & 2.66 & 1.44 (from supplier) & \\
\hline Compacted aggregate $\left(\mathrm{Mg} \mathrm{m}^{-3}\right)$ & 1.75 & 0.92 & \\
\hline Compacted porosity $\left(\mathrm{m}^{3} / \mathrm{m}^{3}\right)$ & $34 \%$ & $36 \%$ & \\
\hline Soil Gs & 2.67 & 2.67 & \\
\hline Compaction testing: & Gravel-base & Stalite-base & Soil \\
\hline$n=5$ & System & System & Alone \\
\hline Compacted density $\left(\mathrm{Mg} \mathrm{m}^{-3}\right)$ & $1.97 \pm 0.005$ & $1.16 \pm 0.005$ & $1.76 \pm 0.005$ \\
\hline Replicate volume $\left(\mathrm{m}^{3}\right)$ & 0.00262 & 0.00262 & 0.00262 \\
\hline Total compacted porosity $\left(\mathrm{m}^{3} / \mathrm{m}^{3}\right)$ & $26 \%$ & $27 \%$ & $34 \%$ \\
\hline Free Drain Moisture $\left(\mathrm{m}^{3} / \mathrm{m}^{3}\right)$ & $17.9 \% \pm 0.85$ & $19.7 \% \pm 0.70$ & $33.26 \pm 0.05$ \\
\hline Observed gravitational porosity & $8 \%$ & $7.3 \%$ & $0.74 \%$ \\
\hline Free drain as $\%$ of total porosity & $30.9 \%$ & $27 \%$ & $2.2 \%$ \\
\hline Plant dry down study & Gravel-base & Stalite-base & \\
\hline$n=15$ & System & System & \\
\hline Compacted density $\left(\mathrm{Mg} \mathrm{m}^{-3}\right)$ & $2.04( \pm 0.01)$ & $1.28( \pm 0.01)$ & \\
\hline Replicate volume $\left(\mathrm{m}^{3}\right)$ & 0.00524 & 0.00524 & \\
\hline $\begin{array}{l}\text { Gravitational drainage moisture* } \\
\left(\mathrm{m}^{3} / \mathrm{m}^{3}\right)\end{array}$ & $0.116 \pm 0.002$ & $0.158 \pm 0.003$ & \\
\hline $\begin{array}{l}\text { Dry endpoint moisture }{ }^{* *} \\
\left(\mathrm{~m}^{3} / \mathrm{m}^{3} @ 1500 \mathrm{kPa} \text { matric tension }\right)\end{array}$ & $0.046 \pm 0.002$ & $0.060 \pm 0.002$ & \\
\hline Plant Available Moisture & $7.0 \%$ & $9.8 \%$ & \\
\hline Infiltration field measure & Gravel-base & Stalite-base & Soil \\
\hline$n=3$ & System & System & Alone \\
\hline Field density $\left(\mathrm{Mg} \mathrm{m}^{-3}\right)$ & 1.98 & 0.80 & 1.78 \\
\hline Infiltration rate $\left(\mathrm{cm} \mathrm{hr}^{-1}\right)$ & $>60$ & $>60$ & 1.24 \\
\hline
\end{tabular}

* Moisture content and Standard Error of mean derived from initial data measures after 9 hours free drainage.

**Moisture content and Standard Error of model fit values derived from predicted values $(\alpha=0.05)$ in simple linear regression (Minitab 14) using negative natural log transformed matric tension and volumetric moisture data. 
'Siouxland' were established in the tubes,grown for 3.5 months (March through July 2006) in a greenhouse in Ithaca, NY, U.S., and kept at a constant $24^{\circ} \mathrm{C}\left(80^{\circ} \mathrm{F}\right)$ under 15 hours HID lighting and daily manual irrigation (Haffner 2008). For nine days, July 6-July 14, 2006, predawn single leaf tissue samples were collected and held in moist sealed bags to transport to the pressure bomb location in a lighted laboratory location. The first pre-dawn observation occurred at 9 hours after final irrigation to column runoff to establish drainage prior to any transpiration demand effect. Pre-dawn plant water potential and volumetric moisture percentage scatter plots were developed to define plant available moisture in the compacted stone-soil matrices, and compare the impact of the differing aggregate source materials. From linear regression on negative natural $\log$ transformed data, moisture content at $1500 \mathrm{kPa}$ was derived. Otherwise, the data collection protocol between Florida and New York were held in common.

Using the same stockpiles of CU and CS blends, field plots were installed and compacted as $64 \mathrm{~m}^{2}\left(689 \mathrm{ft}^{2}\right)$ square blocks to a depth of $60 \mathrm{~cm}$ (24 in) in three $20 \mathrm{~cm}$ (8 in) lifts and compacted to $1.98 \mathrm{Mg} \mathrm{m}^{-3}$ (124 $\left.\mathrm{lb} \mathrm{ft}^{-3}\right)$, verified by sand-cone density tests (Table 1). Infiltration potential was measured three times at random locations in each treatment block using a Cornell Sprinkle Infiltrometer (Ogden et al. 1997) reporting an average of seven readings taken every two minutes during a testing run. Infiltration capacity was measured for discussions on storm water control use when planted with a turf wearing surface (Haffner 2008).

\section{RESULTS}

\section{Initial Studies, 1996-1997}

The difference between observed saturated moisture content and three-hour free-drain moisture losses were consistent with sample density differences, decreasing from $9 \%$ to less than $1 \%$ of total porosity, as density increased from 1.87 to $1.99 \mathrm{Mg} \mathrm{m}^{-3}$ (116.7 to $124.2 \mathrm{lb} \mathrm{ft}^{-3}$ ) (Table 2). The data set was limited to low tension observations due to the repeated breakage of the ceramic pressure plates. Attempts to develop traditional moisture desorption curves were halted. The measured hydraulic conductivity in constant head flow on the two samples (test samples $a, b$ ) were $0.02-0.03 \mathrm{~cm} \mathrm{~s}^{-1}\left(0.08-0.12\right.$ inch s$\left.{ }^{-1}\right)$, in the order of magnitude of a clean, well-graded silty sand and gravel (Atkins 1997).

\section{Planted Study, Florida 2002}

An estimate of plant available moisture percentage from initial drainage to study end was $7.8 \%$ with loamy sand, versus $11.3 \%$ in sandy loam systems. The negative natural log transformed slope coefficients were different $(P<0.001)$ between treatments $(16.9 \%$ for loamy sand versus $14.8 \%$ for sandy loam), demonstrating that the soil texture in two otherwise same systems impacted moisture release behavior (Figure 1), as well as initial porosity in system density resulting from equivalent compaction effort (Table 3 ).

The difference between soil texture treatments within this study were manifest in the first predawn observation (Table 2) at $13.4 \%$ volumetric moisture in loamy sandy systems, versus $16.3 \%$ in sandy loam systems (significantly different at $\alpha=0.05, P<0.001$ ). The difference in density between treatments suggested an impact of the soil texture on stone matrix formation, given the weight ratios and compaction effort were otherwise equivalent. Free drainage time prior to the first data collection in the Florida study

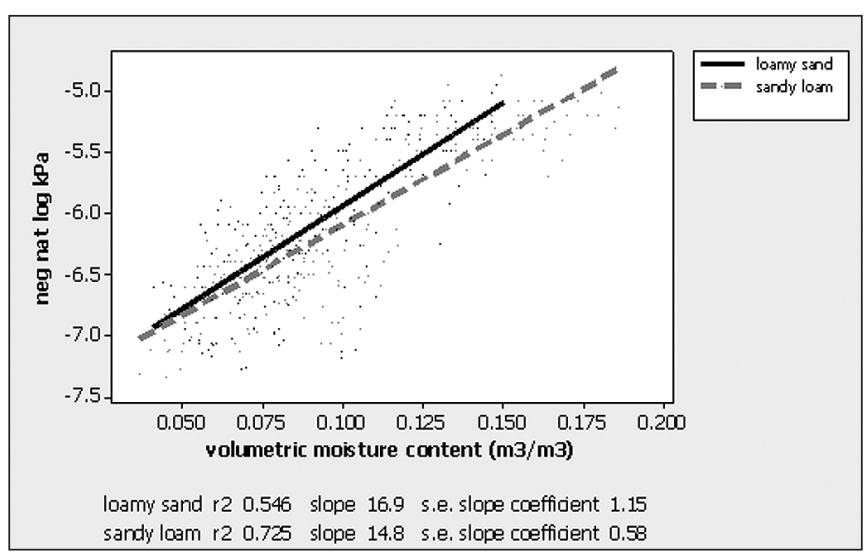

Figure 1. Predawn stem section water potential data transformed into a negative natural log and plotted for linear regression slope analysis for treatment comparison and assignment of high matric tension (assigned at $1200 \mathrm{kPa}$ or -7.09 to determine plant available moisture endpoint). Regression line endpoints correspond with minimum and maximum value observations on the $x$ axis for each treatment.

was 10.5 hours, versus 3 hours of the 1996 data; and the sample depth was $28.6 \mathrm{~cm}$, versus $15.2 \mathrm{~cm}$ (11.3 in and 6 in, respectively, meaning direct comparisons between studies were not feasible).

System densities were lower than expected for paved applications $(90 \%$ assumed target density, rather than at $95 \%$ minimum) due to the nursery container lowering compaction efficacy. The lower densities and associated increased porosity were presumed to have some influence on volumetric plant available moisture, compared to a more compact system.

\section{Planted Study, CU CS Structural Soils 2006}

There was a comparable matrix porosity (Table 4) between aggregates and matrix formation, if the Stalite was treated as a light solid aggregate forming the lattice (apparent Specific Gravity 1.44 provided by the supplier) in phase diagram calculation. Stone matrix formation as soil fines introduced were assumed to have been similar for mixture ratio development (Table 4). While compaction almost eliminated macro-porosity in the soil-only samples (2.2\% of total voids), it was demonstrated to have been conserved in the stone-soil systems (Table 4).

Plant available moisture v/v percentage of the CS was an estimated $9.8 \%$, while the $\mathrm{CU}$ was $7 \%$. Aggregate type influenced the slope of the negative natural log transformed moisture tension regression relationship from $17.3 \%$ in the $\mathrm{CS}$, to $25.4 \%$ for $\mathrm{CU}$ $(P<0.001)$ (Figure 2). Again treatment differences were observed to be a function of the initial pre-dawn observation endpoint of $15.8 \%$ in the $\mathrm{CS}$, versus $11.6 \%$ in the $\mathrm{CU}(P<0.001)$. The aggregate source significantly influenced moisture release behavior, and the Stalite aggregate increased water storage at low matric tension. Plant available moisture was lower in the Cornell study compared to the Florida study, in large part due to a higher compacted density allowed by the rigid tubes designed for planted compaction studies. Infiltration rate observations in both field plots were in excess of $1 \mathrm{~cm} \mathrm{~s}^{-1}\left(0.4\right.$ in s$\left.^{-1}\right)$, at the maximum flow capacity of the Cornell sprinkle infiltrometer, thus the reported values are the maximum flow reading of the tool. The rate was consistent with the order of infiltration magnitude of clean uniform sand. 


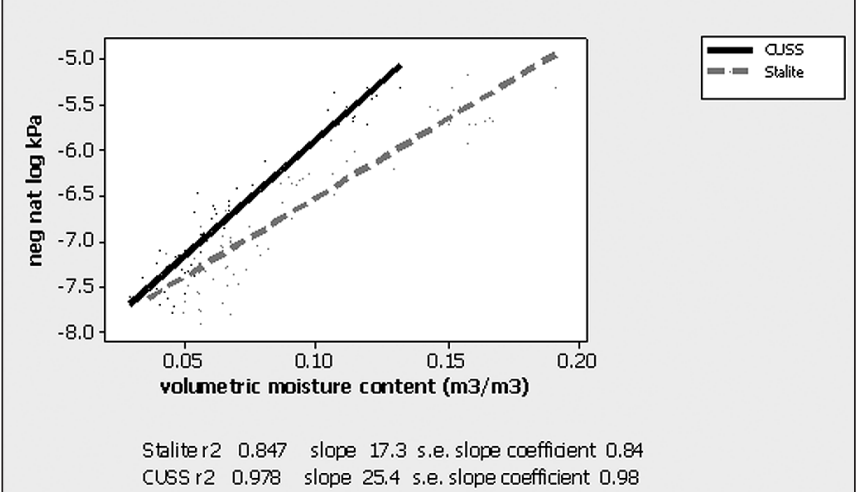

Figure 2. Predawn leaf water potential data transformed into a negative natural log and plotted for linear regression slope analysis for treatment comparison and assignment of high matric potential (assigned at $1500 \mathrm{kPa}$ or $-\mathbf{7 . 3 1}$ to determine plant available moisture endpoint). Regression line endpoints correspond with minimum and maximum value observations on the $x$ axis for each treatment.

\section{DISCUSSION}

After compaction, there was adequate porosity for normal plant growth functions in all soil-aggregate systems tested, above a proposed benchmark minimum of $22 \%$ in urban soils (Craul 1992). The systems drained quickly with a high internal gravitational porosity, providing aeration (Grabosky et al. 2001) which also provided rapid infiltration ability. The rate of rapid drainage can be influenced by the stone-soil mixing ratio, choice of soil, choice of aggregate, and compaction level. Plant available moisture capacity was observed to be a function of compaction intensity, soil type and aggregate type. In all testing cases, the designed soils provided a conservative estimate of plant available moisture from $7 \%$ to $14 \%$ by volume, within normal expectations of field soil conditions. The range of test results generally corresponded to the plant available moisture behavior of loamy sands or some sandy loams (Donahue et al. 1983, Craul 1992), demonstrating the bulk system plant available moisture in the designed stone-soil mixtures are not limited to a contribution from the soil component alone. The test findings were consistent with observed plant response in field installations of pavements using stone-soil systems as base materials in comparison with control pavement sections or nonpaved plant installations (Grabosky et al. 2002; Smiley et al. 2006; Bühler et al. 2007; Grabosky and Bassuk 2008).

The free drainage, infiltration and total porosity data suggest that moisture at field capacity is held weakly. The initial storage may reflect the type of soil in the system (Table 3 ), the type of aggregate used (Table 4) or the level of compaction. Grain surface roughness of aggregates has been demonstrated in fine measurement levels (surface pitting on the micron level) to influence moisture release and movement behavior in clean gravel in small aggregate testing with the assumption that intra-granular and surface features drive water retention behavior (Tokunaga et al. 2003). Surfaces as rough as the manufactured Stalite material (visual surface pitting, on the millimeter scale), as well as internal porosity from the heat expansion need more focused attention before satisfactorily explaining the mode of aggregate surface roughness on the stone-soil system hydraulic properties. The soil component visually coats the aggregate in mixing, and thus is assumed to impact the behavior of the aggregate surface. Studies of smaller clean aggregates describe important considerations needed to fully understand and model low tension moisture drainage behavior in response to distance from a water table or less permeable layers (Tokunaga et al. 2002; Tokunaga et al. 2003), which could translate to plant available moisture storage consideration in these paved systems, suggesting an avenue for future testing. The study presented here differs in aggregate size, compaction level, sample size of observation, and presence of an agricultural soil in the stone matrix and was designed to describe general behavior. However, the data from this study provided evidence that at low tension, the depth of the material will provide a continuum of moisture content increasing with depth to the lower boundary of the designed material and the underlying soil. A middle elevation point of the designed material layer for scaling of bulk system behavior is a reasonable first approximation for future testing and definition (Liu and Dane 1995).

Data from the present studies suggest that the depth of a designed soil profile will impact moisture regimes, thus potentially root system architecture. Moisture content at high matric tension (between 1200 and $1500 \mathrm{kPa}$ ) was characterized by the large amount of aggregate in the system muting soil component moisture release differences at high tension and was found to be fairly consistent across studies which varied by soil and aggregate.

The use or consideration of porous aggregates could be factored in when assessing irrigation needs in normal operations, but should not be assumed to be the only criterion for determining the overall performance of a mix design. Soil chemical aspects such as aggregate and soil $\mathrm{pH}$ and cation exchange capacity ought to be further tested and considered over time. Aggregates must function over time as the load-bearing lattice of the system. As such, aggregate soundness/durability, whether defined from LA abrasion testing or sodium bath aging, must meet the engineering demands of the chosen wearing surface material, the expected load, acceptable settlements over time and pavement service life. Northern climates need to look at aggregate soundness with consideration to freeze-thaw cycles and potentially road salt as well as soundness over time under loading regimes.

Hopefully, these studies will provide some insight into irrigation management strategy and soil volume requirements for stone-soil mixtures. For stormwater management, the infiltration and permeability data of the systems may be helpful for scaling and planning water interception in sheet flows from pavement. It may also be useful in providing a holding reservoir of water for plant use in transpiration or deep infiltration below pavement. While most of the study data describes a dewatering event, initial data in describing the systems dealt with innundation saturation in comparison with a possible total saturation. The differences between de-watering characteristic and iterative recharge of moisture in this manner would likely be subject to measurable hysteresis at low tension in the aspects of the soil-stone interface but bulk behavior would likely mimic the large pore structures in the stone matrix for rapid initial stormwater acceptance.

It is apparent that the systems can be managed and used in design much like agricultural soils in terms of plant available moisture in the total volume of designed root zone. The materials behave similarly to existing field soils in water movement and in plant response, however more research is needed to fairly characterize details of lateral flow and provide predictable sys- 
tem design behavior. Concerns that the stone adds nothing to available moisture holding capacity, but adversely lowers plant available water capacity by soil dilution may not be warranted.

Acknowledgments. We would like to acknowledge the extensive assistance with the Cornell University studies from the Soil Physics lab of Dr. Harold van Es and his technician Robert Schindelbeck. Partial funding for sections of this work was provided by the TREE Fund 2005-2006 and by NUC- Tree Research \& Education Endowment Fund FAC 2004-2007.

\section{LITERATURE CITED}

American Society of Testing Materials. 1997a. Section 4: Construction. In: Annual Book of ASTM Standards. Philadelphia: American Society for Testing and Materials. 04.08 Soil and Rock (I) D420-D4914.

American Association of State Highway and Transportation Officials. 1995. Standard specifications of transportation materials and methods of sampling and testing 17th edition. Washington DC, AASHTO. Part II Tests.

Atkins, H.N. 1997. Section 1.54 Soil Water. In: Highway materials, soils, and concretes 3rd edition. Prentice Hall, Upper Saddle River, NJ.

Bühler, O., P. Kristofferson, and S.U. Larson. 2007. Growth of street trees in Copenhagen with emphasis on the effect of different establishment concepts. Arboriculture \& Urban Forestry 33(5):330-337.

Carolina Stalite Company. 2007. Product specifications and Stalite structural soil specifications. http://www.stalite.com/specifications2.html accessed: December 3, 2007.

Costello, L.R., and K.S. Jones. 2003. Reducing infrastructure damage by tree roots: A compendium of strategies. WCISA. 119 p.

Craul, Phillip J. 1992. Urban Soils in Landscape Design. John Wiley and Sons, Inc. New York, NY.

Donahue, R.L., R.W. Miller, and J.C. Shickluna. 1983. Soils an introduction to soils and plant growth 5th edition. Prentice Hall, Englewood Cliffs, NJ.

Grabosky, J. 1999. Growth response of three tree species in sidewalk profiles. PhD Dissertation Cornell University.

Grabosky, J. 1996. Developing a structural soil material with high bearing strength and increased rooting volumes for street trees under sidewalks. MS Thesis. Cornell University.

Grabosky, J., and N. Bassuk. 2008. Sixth- and tenth-year growth measurements for three tree species in a load-bearing stone-soil blend under pavement and a tree lawn in Brooklyn, New York, U.S. Arboriculture \& Urban Forestry 34(4):265-266.

Grabosky, J., N. Bassuk, and H. van Es. 1996. Further testing of rigid urban tree soil materials for use under pavement to increase street tree rooting volumes. Journal of Arboriculture 22(6):255-263.

Grabosky J., N. Bassuk, L. Irwin, and H. van Es. 2001. Shoot and root growth of three tree species in sidewalk profiles. Journal of Environmental Horticulture 19(4):206-211.

Grabosky, J., N. Bassuk, and B.Z. Marranca. 2002. Preliminary findings from measuring street tree shoot growth in two skeletal soil installations compared to tree lawn plantings. Journal of Arboriculture 28(2):106-108.
Haffner, E.C. 2008. Porous asphalt and turf: Exploring new applications through hydrological characterization of CU Structural Soil and Carolina Stalite Structural Soil. MS Thesis. Cornell University.

Liu, H.H., and J.H. Dane. 1995. Improved computational procedure for retention relations of immiscible fluids using pressure cells. Soil Science Society of America Journal 59:1520-1524.

New York State Department of Transportation. 2006. 2006 Standard specifications; construction and materials. Office of Engineering, Albany, NY. 7.03.

New York State Department of Transportation. 1990. Standard specifications; construction and materials. Office of Engineering, Albany, NY 7.15-7.20.

Ogden, C.B., H.M. van Es, and R.R. Schindelbeck. 1997. Miniature rain simulator for measurement of infiltration and runoff. Soil Science Society of America Journal 61:1041-1043

Scholander, P.F., H.T. Hammel, E.A. Hemmingsen, and E.D. Bradstreet. 1964. Hydrostatic pressure and osmotic potential in leaves of Mangroves and some other plants. Proceedings of the National Academy of Sciences of the USA. 52:119-125

Smiley, E.T., L. Calfee, B. Fraedrich, and E.J. Smiley. 2006. Compaction of Structural Soil and Noncompacted Soils for Trees Surrounded by Pavement. Arboriculture and Urban Forestry 32(4):164-169.

Tokunaga T.K., K.R. Olson, and J. Wan. 2003. Moisture characteristics of Hanford gravels: Bulk, grain-surface, and intragranular components. Vadose Zone Journal 2:322-329.

Tokunaga T.K., J. Wan, and K.R. Olson. 2002. Saturation matric potential relations in gravel. Water Resources Research 38(10).

Topp G.C., Y.T. Galganov, B.C. Ball, and M.R. Carter. 1993. Soil Water Desorption curves. In: M.R. Carter (Ed.). Soil Sampling and Methods of Analysis. Lewis Publishing, Boca Raton, FL. pp 569-580.

Williams L.E., and F.J. Araujo. 2002. Correlations among predawn leaf, midday leaf, and midday stem water potential and their correlations with other measures of soil and plant water status in Vitis vinifera. Journal of American Society of Horticultural Science 127(3):448-454.

Jason Grabosky (corresponding author)

Associate Professor

Ecology, Evolution and Natural Resources

Rutgers University

14 College Farm Road

New Brunswick, NJ 08901, U.S

grabosky@aesop.rutgers.edu

Edward Haffner

Associate Designer

Terry Guen Design Associates

Chicago, Il, 60654, U.S.

Nina Bassuk

Professor and Program Leader

Urban Horticulture Institute

Cornell University

Ithaca, NY 14853, U.S 
Zusammenfassung. Drei Verfahrensweisen zur experimentellen Observation von Teilaspekten von pflanzenverfügbaren Wasserhaltevermögen in verdichteten Stein-Boden-Medien, entwickelt für die Etablierung von Bäumen in Pflasterflächen.

Die verschiedenen verdichteten Medien lieferten einen geschätzten pflanzenverfügbaren Wasseranteil von 7\% - 11\% Volumenprozent, vergleichbar mit einem lehmigen Sand. Veränderungen im Aggregat und Bodenbeeinflussten den ursprünglichen Feldkapazität-Wassergehalt, aber ein hoher Matrix-potentieller Feuchtegehalt blieb bestehen, vermutlich als eine Reflektion der Aggregatzusammensetzung des entwickelten Systems. Ein großer Anteil des pflanzenverfügbaren Wassers wurde schwach in großen Poren gehalten, konsistent mit ähnlichen Infitrationen und Daten über die Durchlässigkeit, und könnte ein Einfluss auf die Wasserspeicherung und Bewässerungsplannung sein, um Schichten von Böden in einer geschichteten Pflastersektion für urbane Vegetation zu nutzen.
Resumen. Tres observaciones experimentales de aspectos de disponibilidad de la capacidad de almacenamiento de agua en suelos compactados fueron designadas para establecimientos de árboles urbanos en situaciones pavimentadas. Los diferentes sustratos compactados proporcionaron un contenido medio de humedad disponible de $7 \%-11 \%$ por volumen, comparable a arenas limosas. Los cambios en agregados y la influencia del contenido de humedad inicial de campo, pero el alto potencial de contenido de humedad fue consistente, presumiblemente como un reflejo del contenido de agregados del sistema designado. Una gran proporción de humedad disponible para la planta fue débilmente retenido en grandes cavidades, consistente con los datos de infiltración y permeabilidad, y podría ser influenciado en almacenaje de agua y planeación del riego para usarse en el suelo en secciones de capas pavimentadas para vegetación urbana. 